\title{
A Research-Based Summary on Trace Minerals for Cattle ${ }^{1}$
}

\author{
João H. Jabur Bittar and Roberto A. Palomares²
}

The cattle production system has several important components, and nutrition plays a crucial role in determining productivity and profitability. Specifically, trace minerals are one essential piece to achieving successful outcomes in cattle production. The effects that trace minerals have on animal performance and health have been widely studied for decades, but results vary and depend on the mineral status and duration of mineral deficiency of the animals (Figure 1). There is an emergence of studies evaluating the use of trace minerals to reduce the detrimental effects of stress (Richeson and Kigley 2001; Roberts et al. 2015) and to enhance immune responses to vaccinations in cattle (Arthington and Havenga 2012; Palomares et al. 2016a; Palomares et al. 2016b; Bittar et al. 2018a; Bittar et al. 2018b; Bittar et al. 2020). Of the ten trace minerals required for cattle, researchers have determined the minimum requirements for seven (NRC 1996): cobalt (Co), copper $(\mathrm{Cu})$, iodine $(\mathrm{I})$, iron $(\mathrm{Fe})$, manganese $(\mathrm{Mn})$, selenium $(\mathrm{Se})$, and zinc $(\mathrm{Zn})$. Even though there is no reliable information regarding dietary requirements of the other three trace minerals (chromium [Cr], molybdenum [Mo], and nickel [Ni]), they are known to be important in cattle nutrition; especially molybdenum, due to negative effects observed when an excessive amount is fed to cattle. This is thought to be due to Mo binding to other minerals like $\mathrm{Cu}$, making them unavailable to the animal (Suttle 1991).

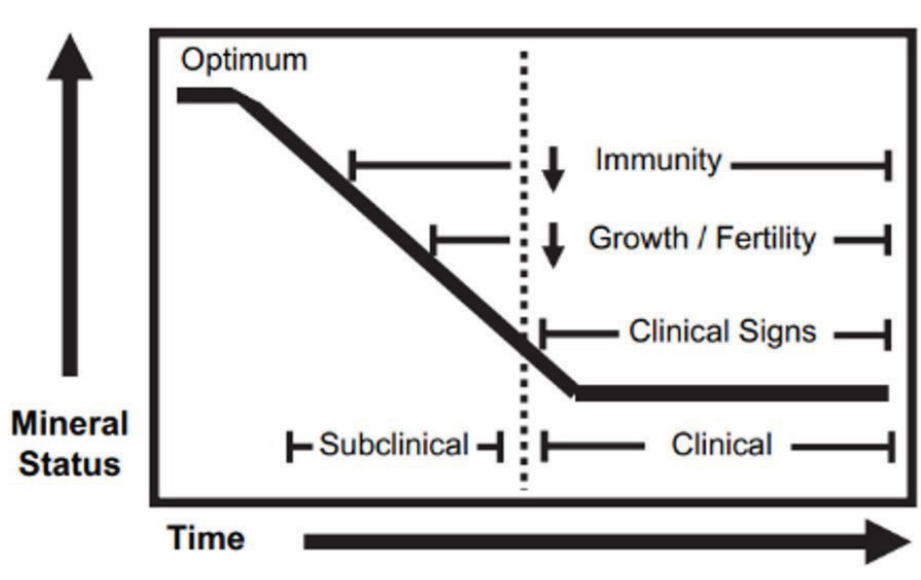

Figure 1. The effects of trace mineral deficiency on the health and performance of cows and calves.

Credits: Adapted from Wikse (1992) and Olson (2007)

Despite a few regional exceptions with a natural excess of trace minerals in the soil, grass, and water that can lead to toxicity from ad libitum ingestion, deficiency is the most common trace mineral problem affecting cattle production and health. The predominant trace mineral deficencies in the diets of grazing cattle in the Southeast, particularly in Florida, are copper, selenium, and zinc (Arthington 2000; Stewart 2017). Therefore, there is increased research to inform management efforts so that producers can efficiently supplement cattle with trace minerals and ensure adequate bioavailability levels. Note that the diet may contain many other minerals with antagonistic characteristics that can affect the absorption of trace minerals in cattle. Examples of these are molybdenum and sulfur, which can lead to mineral imbalance even when recommended levels of

1. This document is VM245, one of a series of the Veterinary Medicine-Large Animal Clinical Sciences Department, UF/IFAS Extension. Original publication date October 2021. Visit the EDIS website at https://edis.ifas.ufl.edu for the currently supported version of this publication.

2. João H. Jabur Bittar, DVM, MSc., Ph.D., Department of Large Animal Clinical Sciences, UF College of Veterinary Medicine; and Roberto A. Palomares, DVM, MS, Ph.D., DACT, Department of Population Health, College of Veterinary Medicine, University of Georgia, Athens, GA; UF/IFAS Extension, Gainesville, FL 32611.

The Institute of Food and Agricultural Sciences (IFAS) is an Equal Opportunity Institution authorized to provide research, educational information and other services

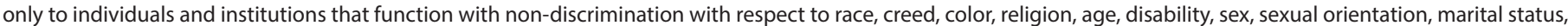

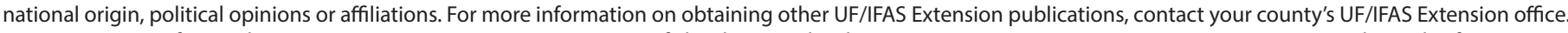
U.S. Department of Agriculture, UF/IFAS Extension Service, University of Florida, IFAS, Florida A \& M University Cooperative Extension Program, and Boards of County Commissioners Cooperating. Nick T. Place, dean for UF/IFAS Extension. 
trace minerals are supplemented. Adequate levels of trace minerals must be available because they are involved in cattle physiology. Trace minerals play a critical role in overall growth (Spears and Kegley 2002), enzyme structure, and nucleic acid replication, and are critical to the immune system in general.

Copper $(\mathrm{Cu})$ is important in mitochondrial energy production and plays an essential role in neutralizing reactive oxygen species (ROS) by participating in dismutase superoxidase activity. The phagocyte killing activity and functions of neutrophils and monocytes, which are of high importance in the innate immune response of cattle, also depend on copper (Linder 1991). With regard to the adaptive arm of the immune system, defective antibody production and lowered cell-mediated immunity are associated with copper deficiency in mice (Sherman 1992). Although this has not been demonstrated in cattle, a similar effect would be expected due to similarities in the mechanisms that drive these processes. On the other hand, improved antibody production and leukocyte proliferation were seen in calves with additional supplementation with injectable trace minerals (Arthington and Havenga 2012; Palomares et al. 2016a; Palomares et al. 2016b; Bittar et al. 2018a; Bittar et al. 2020).

Selenium (Se) deficiency is the primary cause of nutritional myodegeneration ("white muscle disease") in cattle. Even after a massive preventative effort, this disease still causes significant losses. Even marginal selenium deficiency can cause subclinical effects in cattle and strongly influence the immune system, affecting cattle health and performance. Cows experiencing this disease typically have weak calves with increased susceptibility to diseases, poor reproductive performance, and a higher incidence of retained fetal membrane. The function of selenium in the immune system is based on its participation in the structure and function of several enzymes directly linked to the neutralization of ROS. Among them, glutathione peroxidase is a major antioxidant reducing the excessive ROS and cell damage due to oxidative stress (Herdt and Hoff 2011). There is evidence that Se deficiency in cattle increases the pathogenicity of some viruses (Beck 2007) and negatively affects neutrophil migration into tissue that experiences inflammation (Maddox et al. 1999). In contrast, Se supplementation enhances both arms of the adaptive immune system, including antibody production and T-cell number and functions (Maggini et al. 2007).

Zinc $(\mathrm{Zn})$ is one of the trace minerals with a broader range of influences in the animal body. It participates in the structure and function of more than 2,500 enzymes involved in metabolism, DNA replication, and the immune system. Zinc is important in several aspects of the immune response, including participation in the proliferation and differentiation of lymphocytes, function and transit of neutrophils and macrophages, pro-inflammatory cytokines' production, regulation, and secretion (specifically IL-2), T-cell clonal expansion, and activation and antibody production by the B-cells (Palomares et al. 2016a).

Recent studies in calves showed beneficial effects of the strategic use of trace minerals in an injectable formulation on the humoral immune response to common vaccines (Arthington and Havenga 2012; Palomares et al. 2016a; Palomares et al. 2016b; Roberts et al. 2016; Bittar et al. 2018a; Bittar et al. 2020). Note that the cattle population evaluated in these studies did not have trace mineral deficiency. In this regard, the authors offered additional scientific data to reinforce and support the beneficial effect of supplemental trace minerals even in cattle with sufficient mineral levels. Several trace mineral supplement formulations with different administration routes are available to be used in cattle because there is no "one size fits all" approach to trace mineral supplementation. Producers need to consider several factors when making this decision. These factors include: the initial mineral status of the herd (normal levels or borderline to severe deficiencies), duration of supplementation required, the bioavailability of mineral components, ease of administration (injectable, bolus or capsule, salt block, or feed), and whether the formulation will be a single or multiple mineral supplementation. Nowadays, there is an ongoing debate regarding the preferred route of trace minerals administration. One of the advantages of oral trace minerals formulation is the administration ease because there is no need for handling the herd in restraint facilities. Nonetheless, the constant maintenance of the feeder to ensure sufficient availability of trace minerals is required, and variation in dry matter intake can account for heterogenous supplementation on an individual basis. For instance, weaker cattle that might receive more benefits from mineral supplementation will be the ones with lower dry matter and therefore trace mineral intake, especially if inadequate feed bunk space exists. On the other hand, boluses and capsules provide a homogenous administration through the herd, ensuring adequate dosing. However, the additional and unpleasant animal handling needs to be considered as well as the relatively slow rise in trace mineral concentration in the blood due to slow absorption that may occur depending on the formulation. Despite the need for cattle restraint, the injection of trace minerals has several benefits, such as adequate dosing depending on animal needs and a quick rise in tissue trace 
mineral concentration. Injectable formulations also have the benefit of allowing producers to administer the trace minerals in situations in which the dry matter intake might not be well controlled and when it is relatively challenging to supplement or achieve higher levels of dry matter intake. Therefore, it is a somewhat easier administration route on a large scale when compared to bolus or capsule.

There are some benefits for trace mineral administration, even when sufficient concentrations are present in cattle. Specific benefits have been observed in both innate and adaptive immune responses. The benefits of trace minerals in the innate immune response, including neutrophil and macrophage transit and function, significantly prevent the beginning and development of an infection. The effects of strategically using trace minerals benefit the adaptive immune response, by enhanced antibody production and T-cell response, and provide the most benefit in situations before vaccination, disease challenges, and stressors. Additionally, trace mineral use in newborns, especially dairy calves, can be justified due to the lower concentration of some trace minerals in colostrum. It has been reported that calves supplemented within the first month of life with an injectable and multiple trace mineral formulation had reduced morbidity and mortality (Teixeira et al. 2014).

Different analytical approaches can assess the trace mineral profile of an animal. The hepatic mineral analysis represents the gold standard to evaluate animals' mineral status.

However, mineral analysis in whole blood or serum still has value due to the practicality of the collection; nonetheless, interpretation should be performed with care. Acceptable ranges of trace mineral concentrations in blood (serum and whole blood) and hepatic tissue can be found in Tables 1 and 2, respectively. A common challenge in analyzing trace minerals and interpreting the test results is the inconsistency in the units used for their measurements. A conversion table to facilitate standardization related to trace minerals communication is available (Table 3). It is crucial when managing trace mineral nutrition in a holistic approach to assess the initial mineral status of cattle, as well as dietary contributions of trace minerals from feed, grass, water, and feed supplements. This additional information allows for more informed decisions about the sources of minerals and potential inhibitors, including the high levels of undesired macrominerals and trace minerals being ingested by cattle.

In summary, cattle health and productivity can benefit from trace minerals supplementation when used in accordance with the guidelines described here. Nevertheless, supplementation of trace minerals is not a single solution but an aid in achieving optimal cattle performance. Other factors need to be addressed before determining the source, level, and management strategy for mineral supplementation. From a broad perspective, the most important and basic factors to consider when optimizing cattle production include, but are not limited to, adequate overall nutrition, low-stress cattle handling, management, biosecurity programs, and reduced pathogen burden in cattle housing.

\section{Conclusion}

Producers can utilize mineral supplementation to improve cattle production and herd health, which has the potential to reduce antibiotic usage. This is especially important because demands for higher food quality are continually increasing. Nonetheless, food animal professionals (veterinarians, nutritionists, animal scientists, and agronomists) have to take a teamwork approach in analyzing, guiding, and working with producers to bring exponentially high standards to the cattle industry and consequently to consumers.

\section{References}

Arthington, J.D. 2000. Essential Trace Minerals for Grazing Cattle in Florida. AN086. Gainesville: University of Florida Institute of Food and Agricultural Sciences.

Arthington, J. D., and L. J. Havenga. 2012. "Effect of Injectable Trace Minerals on the Humoral Immune Response to Multivalent Vaccine Administration in Beef Calves." J. Anim. Sci. 90:1966-1971. https://doi.org/10.2527/ jas.2011-4024

Beck, M. A. 2007. "Selenium and Vitamin E Status: Impact on Viral Pathogenicity." J. Nutr. 37(5): 1338-40. https://doi. org/10.1093/jn/137.5.1338

Bittar, J. H. J., D. J. Hurley, A. R. Woolums, N. A. Norton, C. E. Barber, F. Moliere, L. J. Havenga, and R. A. Palomares. 2018a. "Effects of Injectable Trace Minerals on the Immune Response to Mannheimia haemolytica and Pasteurella multocida Following Vaccination of Dairy Calves with a Commercial Attenuated-Live Bacterin Vaccine." The Prof. Anim. Sci. 34:59-66. https://doi.org/10.15232/ pas.2017-01695

Bittar, J. H. J., A. Hoyos-Jaramillo, D. J. Hurley, A. R. Woolums, L. J. Havenga, J. M. Lourenço, G. Barnett, V. Gomes, J. T. Saliki, D. D. Harmon, and R. A. Palomares. 2018b. "Effect of Injectable Trace Minerals Administered Concurrently with a Modified Live Virus Vaccine on LongTerm Protection against Bovine Viral Diarrhea Virus Acute 
Infection in Dairy Calves." Research in Veterinary Science 119:250-258. https://doi.org/10.1016/j.rvsc.2018.07.003

Bittar, J. H. J., R. A. Palomares, D. Hurley, A. Hoyos-Jaramillo, A. Rodriguez, A. Stoskute, B. Hamrick, N. Norton, M. Adkins, J. Saliki, S. Sanchez, and K. Lauber. 2020.

"Immune Response and Onset of Protection from Bovine Viral Diarrhea Virus 2 Infection Induced by Modified-Live Virus Vaccination Concurrent with Injectable Trace Minerals Administration in Newly Received Beef Calves." Vet. Immunol. and Immunopathology 225(2020): 110055. https://doi.org/10.1016/j.vetimm.2020.110055

Herdt, T. H., and B. Hoff. 2011. "The Use of Blood Analysis to Evaluate Trace Mineral Status in Ruminant Livestock." Vet. Clin. Food Anim. 27:255-283. https://doi.org/10.1016/j. cvfa.2011.02.004

Linder, M. C. 1991. "Biochemistry of Copper." In Biochemestry of the Elements, edited by E. Frieden. New York, NY: Plenum Press. https://doi. org/10.1007/978-1-4757-9432-8

Maddox, J. F., K. M. Aherne, C. Channa Reddy, and L. M. Sordillo. 1999. "Increased Neutrophil Adherence and Adhesion Molecule mRNA Expression in Endothelial Cells during Selenium Deficiency." J. Leuk. Biol. 65:658-664. https://doi.org/10.1002/jlb.65.5.658

Maggini, S., E. S. Wintergerst, S. Beveridge, and D. H. Hornig. 2007. "Selected Vitamins and Trace Elements Support Immune Function by Strengthening Epithelial Barriers and Cellular and Humoral Immune Responses." Br. J. Nutr. 98:S29-35. https://doi.org/10.1017/S0007114507832971

National Research Council. 1996. Nutrient Requirements of Beef Cattle. Washington, D.C.: National Research Council.

Olson, K. C. 2007. "Management of Mineral Supplementation Programs for Cow-Calf Operations." Veterinary Clinics: Food Animal Practice 23(1): 69-90. https://doi. org/10.1016/j.cvfa.2006.11.005

Palomares, R. A., D. J. Hurley, J. H. J. Bittar, J. T. Saliki, A. R. Woolums, F. Moliere, L. J. Havenga, N. A. Norton, A. J. Sigmund, C. E. Barber, M. L. Berger, M. J. Clark, and M. A. Fratto. 2016a. "Effects of Injectable Trace Minerals on Humoral and Cell-Mediated Immune Responses to Bovine Viral Diarrhea Virus, Bovine Herpes Virus 1 and Bovine
Respiratory Syncytial Virus Following Administration of a Modified-Live Virus Vaccine in Dairy Calves." Vet. Immunol. Immunopat. 178:88-98. https://doi.org/10.1016/j. vetimm.2016.07.003

Palomares, R. A., D. J. Hurley, F. Moliere, A. R. Woolums, L. J. Havenga, N. A. Norton, A. J. Sigmund, C.E. Berger, M. L. Berger, M. J. Clark, and M. A. Fratto. 2016b. "Effect of Injectable Trace Minerals on the Immune Response to Bacterial Antigens after Administration of an Attenuated-Live Bacterin in Dairy Calves." $29^{\text {th }}$ World Buiatrics Congress, July $3^{\text {rd }}-8^{\text {th }}, 2016$, Dublin, Ireland.

Richeson, J. T., and E. B. Kegley. 2011. "Effect of Supplemental Trace Minerals from Injection on Health and Performance of Highly Stressed, Newly Received Beef Heifers." Prof. Anim. Sci. 27:461-466. https://doi.org/10.15232/ S1080-7446(15)30519-2

Roberts, S. L., N. D. May, C. L. Brauer, W. W. Gentry, C. P. Weiss, J. S. Jennings, and J. T. Richeson. 2015. "Effect of Injectable Trace Mineral Administration on Health, Performance and Vaccine Response of Newly Received Beef Cattle." J. Anim. Sci. 93(suppl. 2): 2.

Sherman, A.R. 1992. "Zinc, Copper, and Iron Nutriture and Immunity. History of Nutritional Immunology." $75^{\text {th }}$ Meeting of the Federation of American Societies for Experimental Biology, Atlanta, GA.

Spears, J. W., and E. B. Kegley. 2002. "Effect of Zinc Source (Zinc Oxide vs. Zinc Proteinate) and Level on Performance, Carcass Characteristics, and Immune Response of Growing and Finishing Steers." J. Anim. Sci. 80:2747-2752. https:// doi.org/10.2527/2002.80102747x

Stewart, L. 2017. "Mineral Supplements for Beef Cattle." UGA Cooperative Extension Bulletin 895. Athens, GA: University of Georgia.

Suttle, N. F. 1991. “The Interactions between Copper, Molybdenum, and Sulfur in Ruminant Nutrition." Annu. Rev. Nutr. 11:121-40. https://doi.org/10.1146/annurev. nu.11.070191.001005

Teixeira, A. G. V., F. S. Lima, M. L. S. Bicalho, A. Kussler, S. F. Lima, M. J. Felippe, and R. C. Bicalho. 2014. "Effect of an Injectable Trace Mineral Supplement Containing Selenium, Copper, Zinc, and Manganese on Immunity, Health, and Growth of Dairy Calves." J. Dairy Sci. 97:4216-4226. https://doi.org/10.3168/jds.2013-7625 
Table 1. Reference ranges for bovine trace mineral concentrations in serum and whole blood. Adapted from Herdt and Hoff, 2011.

\begin{tabular}{|l|c|c|}
\hline & Adults and Growing Calves & Neonates \\
\hline Cobalt $(\mathrm{ng} / \mathrm{mL})$ & $0.17-2.0$ & $0.18-2.3$ \\
\hline Copper $(\mu \mathrm{g} / \mathrm{mL})$ & $0.6-1.1$ & $0.3-1.0$ \\
\hline Iron $(\mu \mathrm{g} / \mathrm{mL})$ & $1.1-2.5$ & $0.25-1.7$ \\
\hline Manganese $(\mathrm{ng} / \mathrm{mL})$ & $0.9-6.0$ & $1.0-4.0$ \\
\hline Molybdenum $(\mathrm{ng} / \mathrm{mL})$ & $2.0-35$ & $1.0-15$ \\
\hline Selenium $(\mathrm{ng} / \mathrm{mL})$ & $65-140$ & $20-70$ \\
\hline Whole-blood selenium $(\mathrm{ng} / \mathrm{mL})$ & $120-300$ & $100-250$ \\
\hline Zinc $(\mu \mathrm{g} / \mathrm{mL})$ & $0.6-1.9$ & $0.6-1.75$ \\
\hline
\end{tabular}

Table 2. Reference ranges for bovine hepatic trace mineral concentrations. Values are expressed on a dry tissue basis. Adapted from Herdt and Hoff, 2011.

\begin{tabular}{|l|c|c|}
\hline & Adults and Growing Calves & Neonates \\
\hline Cobalt $(\mu \mathrm{g} / \mathrm{g})$ & $0.10-0.4$ & $0.06-0.4$ \\
\hline Copper $(\mu \mathrm{g} / \mathrm{g})$ & $50-600$ & $125-650$ \\
\hline Iron $(\mu \mathrm{g} / \mathrm{g})$ & $140-1000$ & $160-1000$ \\
\hline Manganese $(\mu \mathrm{g} / \mathrm{g})$ & $5-15$ & $3.5-15$ \\
\hline Molybdenum $(\mu \mathrm{g} / \mathrm{g})$ & $1-4$ & $0.6-3$ \\
\hline Selenium $(\mu \mathrm{g} / \mathrm{g})$ & $0.7-2.5$ & $1.5-3.5$ \\
\hline Zinc $(\mu \mathrm{g} / \mathrm{mL})$ & $90-400$ & $120-400$ \\
\hline
\end{tabular}

Table 3. Useful mass unit concentration conversions. Adapted from Herdt and Hoff, 2011.

$$
\begin{aligned}
& \mathrm{ng} / \mathrm{mL}=\mu \mathrm{g} / \mathrm{L}=\text { parts per billion }(\mathrm{ppb}) \\
& \mu \mathrm{g} / \mathrm{mL}=\mathrm{mg} / \mathrm{L}=\text { parts per million }(\mathrm{ppm}) \\
& \mathrm{ng} / \mathrm{g}=\mu \mathrm{g} / \mathrm{kg}=\text { parts per billion }(\mathrm{ppb}) \\
& \mu \mathrm{g} / \mathrm{g}=\mathrm{mg} / \mathrm{kg}=\text { parts per million }(\mathrm{ppm})
\end{aligned}
$$

Wikse, S. 1992. "The Relationship of Trace Element

Deficiencies to Infectious Diseases of Beef Calves." In

Proceedings of the Texas Beef Cattle Short Course. 8. College

Station, TX: Texas A\&M University. 